\title{
Construction and validation of nursing diagnoses for individuals with diabetes in specialized care*
}

\author{
Construção e validação de diagnósticos de enfermagem para \\ pessoas com diabetes na atenção especializada \\ Construcción y validación de diagnósticos de enfermería para \\ personas con diabetes en la atención especializada
}

\section{Luciana Gomes Furtado Nogueira' ${ }^{1}$ Maria Miriam Lima da Nóbrega²}

\author{
* Extract from the thesis "Subconjunto \\ Terminológico da CIPE para pessoas com \\ Diabetes Mellitus na atenção especializada”, \\ Nursing Postgraduate Program, Federal \\ University of Paraíba, 2014. \\ ${ }^{1}$ Professor, Faculty of Nursing of São Vicente de \\ Paula, João Pessoa, Paraíba, Brazil. \\ ${ }^{2}$ Assistant Professor, Department of Public \\ Health and Psychiatric Nursing, Federal \\ University of Paraíba, João Pessoa, Paraíba, Brazil.
}

Correspondence Addressed to: Luciana Gomes Furtado Nogueira Health Sciences Center, Federal University of Paraíba, Campus I CEP 58051-900 - João Pessoa, Paraíba, Brazil

E-mail: lugofurtado@hotmail.com

\section{ABSTRACT}

Objective: To construct statements of nursing diagnoses related to nursing practice for individuals with diabetes in Specialized Care, on the basis of the Database of Nursing Practice Terms related to diabetes, in the International Classification for Nursing Practice $\left(\mathrm{ICNP}^{\circledast}\right)$ and in the Theory of Basic Human Needs and to validate them with specialist nurses in the area. Method: Methodological research, structured into sequential stages of construction, cross-mapping, validation and categorization of nursing diagnoses. Results: A list was indicated of 115 statements of diagnostic, including positive, negative and improvement statements; 59 nursing diagnoses present in and 56 nursing diagnoses absent from the ICNP ${ }^{\circledR}$ Version 2011. 66 diagnoses with $\mathrm{CVI} \geq 0.50$ were validated, being categorized on the basis of human needs. Conclusion: It was observed that the use of the ICNP ${ }^{\circledR} 2011$ favored the specifications of the concepts of professional practice in care with individuals with diabetes.

\section{DESCRIPTORS:}

Nursing Diagnosis; Diabetes Mellitus; Classification; Terminology. 


\section{INTRODUCTION}

Throughout its history, Nursing has presented a need to construct its own consensual and objective vocabulary for its practice. In order to meet this need, the International Council of Nurses (ICN) developed the International Classification for Nursing Practice (ICNP ${ }^{\circledR}$ ), which has been in a process of consolidation at global level as one of the trends towards harmonizing communication and exchanging information between nurses, with a view to representing nursing practice in Health Information Systems ${ }^{(1)}$.

Notable in this context are nursing diagnoses, initially presented by the $\mathrm{ICNP}^{\circledast}$, as one of the components of the classification, representing one of the elements of nursing practice: what nurses do with regard to certain human needs for producing given outcomes, with diagnoses receiving a connotation of human need ${ }^{(2)}$. In more recent versions, in a presentation with new content, including pre-combined diagnoses, this connotation is directed towards situations of interest to nursing, which may be positive, negative or improving ${ }^{(2)}$.

In this study, we prioritize the construction of nursing diagnoses for a client base of individuals with diabetes receiving specialized care, considering that caring for individuals with diabetes is a challenge for healthcare professionals, since it not only assists with control of the symptoms, with living with disabilities and with adaptation to the social and psychological changes arising from the disease, but also with teaching them how to live and manage the disease in the face of situations arising on an everyday basis, raising their awareness of the need for changes in behavior throughout the trajectory of the disease and of life ${ }^{(3)}$.

As a professional in a multidisciplinary team, in order to implement all of the actions aimed at individuals with diabetes, the nurse must orient these through the nursing process, a scientific methodology in which technical-scientific and human knowledge are applied to care for patients, providing scientific support, security and guidance for the activities carried out, contributing to greater credibility, competence and visibility of nursing and consequently, greater autonomy and professional satisfaction ${ }^{(4)}$. This nursing process must be based on a theory of nursing which directs its stages, and this theory must be understood by nurses and be appropriate to the reality into which the nursing service finds itself inserted ${ }^{(4)}$.

In Brazil, the theory of nursing which significantly modified practice in the area was the Theory of Basic $\mathrm{Hu}^{-}$ man Needs (TNHB), developed by the Brazilian the rotation, Wanda de Aguiar Horta, which defined the focus of Nursing work as raising human beings to a state of equilibrium, i.e. of health, in order to meet their basic human needs, constituted conceptually as nursing problems ${ }^{(5)}$.

Given this context, the TNHB is used in this study as a theoretical model for categorizing nursing diagnoses for individuals with diabetes mellitus under specialized care at the Lauro Wanderley University Hospital (HULW/UF$\mathrm{PB}$ ), with this justified by the fact that it is the theoretical model which forms the basis of the Systematization Plan for Nursing Care (SAE) of the hospital in question.
The Grupo de Estudos e Pesquisas em Fundamentos da Assistência de Enfermagem [Study and Research Group into Nursing Care Fundamentals] (GEPFAE), which is integrated with the ICNP ${ }^{\circledR}$ Center in Brazil, has developed studies which aim to integrate $\mathrm{ICNP}^{\circledR}{ }^{\circledR}$ terminology into nursing practice, notably in the databases of terms of specialized nursing language, directed towards various specialties.

In this way, considering the involvement of Nursing in the attempt to structure the care process, with the use of a nursing classification system, specifically the $\mathrm{ICNP}^{\circledR}$, and the fact that the University Hospital is a benchmark in the specialty of endocrinology, it is relevant to carry out studies which permit a contribution of nursing assistance to the Endocrinology Clinic sector.

This article has as its objective the construction statements of nursing diagnostic related to nursing practice for individuals with diabetes under Specialized Care on the basis of the $\mathrm{ICNP}^{\circledR}$ and the TNHB and their validation with nurses specializing in the area.

\section{METHOD}

A study of methodological type, developed within the Endocrinology Clinic and the Medical and Statistical Archive Service of the HULW/UFPB. Before being developed, the research project was assessed by the Research Ethics Committee of the HULW/UFPB, observing the Directives and Regulating Provisions provided in Resolution No. 466/2012 $2^{(6)}$, from which it received a favorable opinion, under CAAE 19382413.0.0000.5183.

In the construction statements of nursing diagnostic, the Database of nursing language terms related to diabetes mellitus, in the specialized care of the HULW/UFPB was considered, as were the orientations of the ICNP ${ }^{\circledR}$, in accordance with ISO 18.104. The orientation is that the nursing diagnostic must be expressed both through the judgment made for a given focus of care and by clinical finding representing an altered state. Since it is mandatory to have a judgment descriptor and a descriptor by focus, this (area of care) was chosen. For the clinical finding, the expression is present in the Standard ISO/TS 22789:2010 must be followed. In addition to these two possibilities, a diagnostic may also be associated with a potential, indicating the risk or chance of occurrence.

The cross-mapping of nursing diagnoses process so constructed and the concepts of the ICNP ${ }^{\circledR}$ Version 2011 were initially implemented with the insertion of the statements of nursing diagnostic in Excel spreadsheets, normalized on the basis of the ICNP ${ }^{\circledR}$ 2011. Following this, these were imported into the Access for Windows program and submitted to the cross-mapping process with the statements of diagnostic present in the ICNP ${ }^{\circledR} 2011$, resulting in a list with nursing diagnoses present in and absent from the ICNP ${ }^{\circledR} 2011$.

For the statements which were absent, a process of analysis was carried out regarding the similarity and scope of the pre-combined concepts of the ICNP ${ }^{\circledR}$, using the criteria proposed by Leal ${ }^{(7)}$, which establish: whether the $\mathrm{ICNP}^{\circledR}$ criterion is similar to the identified one; whether it 
is more extensive; whether it is more restrictive; and whether there is no agreement, i.e. new statements.

At the stage of Validation statements of nursing diagnostic by specialists, in order to establish the group of specialists, the following inclusion criteria were used: nurses with a qualification of Master's degree as a minimum, who had worked with nursing diagnoses and with the $\mathrm{ICNP}^{\circledR}$ and whose focus was diabetes in health care, teaching and/or research.

The selection of this group of specialists was carried out via the Lattes Platform, using terms by subject: diabetes mellitus, Nursing and $\mathrm{ICNP}^{\circledR}$, giving priority to researchers in the field and authors of specific articles on the topic in question. Following the selection of 44 specialists, who fulfil the inclusion criteria, invitation letters were submitted to 18 of them via the Internet. Of the invitations submitted and contacts made, a final sample of 13 specialists resulted, who were included in this study.

The method of the Content Validity Index (CVI), which measures the proportion or percentage of judges who ${ }_{8}$ agree with given aspects of the instrument and of its items , was used, represented by the statements of nursing diagnostic, which were evaluated with regard to their use in nursing practice in caring for individuals with diabetes.

Via this CVI method, it is initially possible to analyze each item individually and then the instrument as a whole. A scale of Likert type was used, with scores of one to four, in order to evaluate the representativeness of its use in nursing practice. The nursing diagnoses, which obtained agreement of at least $\mathrm{CVI} \geq 0.50$, were considered as valid.

In the categorization stage, according to the TNHB, the diagnoses were classified in accordance with the subcategories of Psychobiological, Psychosocial and Psychospiritual Needs.

\section{RESULTS}

In view of the findings of this study, a list of 115 nursing diagnoses was constructed, which was submitted to a process of analysis of similarity and scope, in order to identify the statements of diagnostic present in and absent from the $\mathrm{ICNP}^{\circledR}$ 2011. The results demonstrated that 41 nursing diagnoses were equal; 10 similar; 4 more extensive; 45 more restricted, with 15 showing no agreement. The nursing diagnoses classified as equal and similar were regarded as constant. In this way, 51 constant and 64 non-constant nursing diagnoses were verified in the ICNP ${ }^{\circledR}$ Version 2011 out of the total of 115 constructed nursing diagnoses.

After the construction of the 115 statements of nursing diagnoses/outcomes, these were submitted to a validation process for their use in nursing practice in caring for individuals with diabetes by 13 female specialists, the majority in the over-50 age group (53.9\%), holding a Doctorate in Nursing Education (84.6\%), with over 25 years' professional experience (69.2\%) and over 16 years' experience in assisting individuals with diabetes.

In this study, of the 115 nursing diagnoses submitted to the validation process, 16 achieved a CVI $\geq 0.80$ (14\%), 50 achieved a CVI $\geq 0.50$ and $\leq 0.80$ (43.4\%), and 49 achieved a CVI $\leq 0.50$ (42,6\%). Diagnoses were validated with a CVI $\geq 0.50$, resulting in 66 nursing diagnoses, categorized in accordance with the $\mathrm{NHB}(5)$ and distributed as follows: Psychobiological Needs: 52 statements (79\%) and Psychosocial Needs: 14 statements (21\%). No indicators were identified for the construction of diagnoses for Psychospiritual Needs.

\section{DISCUSSION}

The statements of constructed and validated in this study translate the focus of nursing care for individuals with diabetes under Specialized Care at the HULW/UFPB and represent a guiding element of the management of nursing care for this client base, insofar as it favors better clinical practice and a better decision-making process, assisting it in all of its complexity.

Among the Psychobiological Needs, that of oxygenation in individuals with diabetes demonstrated alterations relating to macrovascular complications, responsible for cardiovascular illnesses (acute myocardial infarction (AMI), cerebral vascular accident (CVA) and coronary artery disease (CAD)), highlighted as the principal cause of morbimortality associated with diabetes ${ }^{(9)}$. Considering the relevance of these aspects, the Dyspnea nursing diagnostic was elaborated (specify).

The need for hydration is related to the physiology of water, electrolytic and acid-based regulation. In diabetes, some complications may trigger imbalances in this need, such as diabetic nephropathy, diabetic ketoacidosis, insulin therapy and cardiopathies. For this need, the Edema nursing diagnostic was elaborated (specify degree and location).

With regard to the need for nutrition, within the context of the diabetes, healthy eating is listed as one of the fundamental elements for preventing and treating it and is included in the list of self-care and health education measures. It is recognized as a tool which serves to control glycemia and arterial pressure, for maintaining or losing weight, which contributes to a reduction in the risks of cardiovascular illnesses ${ }^{(9)}$. In the face of the relevance of nutrition in control of the diabetes, the nursing diagnoses Appetite preserved, Appetite impaired, Slimming, Nutrition preserved, Nutrition impaired, Obesity, Adequate body weight and Overweight were elaborated.

In specialized care, the nutritional approach is supported by the nutrition professional and add his into nutritional therapy must be monitored in follow-up visits, investigating the presence of episodes of hypoglycemia, hypoglycaemia, dyslipidemias, accelerated weight loss or weight gain and an increase in pressure levels ${ }^{(9)}$.

For the aspect of the need for sleep and rest, some variables which influence its quantity and quality may be present, including: age and state of development; psychosocial influences; lifestyle; environmental conditions; health disturbances and clinical interventions. These influences may be responsible for a number of sleep disturbances (insomnia, sleep deprivation, narcolepsy, parasomnias and sleep apnea), which have been associated with the occurrence of various health problems, including cardiovascular disease, diabetes, obesity and depression ${ }^{(10)}$. Given this context, the nursing diagnoses Insomnia, Effective rest, Sleep preserved and Sleep impaired were elaborated for this need. 
The needs of exercise, physical activity and locomotion in the treatment of diabetes are directed towards regular physical activity, which constitutes one of the principal forms of health behavior to be adopted, since it contributes to improving glycemic control, reducing risk factors for coronary disease, reducing weight and promoting well-being $^{(11)}$. At the same time, in order to initiate physical activity, an evaluation is necessary of the current status of the client regarding metabolic control, the potential for self-care and the presence of complications. This evaluation must have a multi-professional focus, including: doctor, nurse, nutritionist and physical education instructor ${ }^{(9)}$. Considering the benefits of this need for individuals with DM, the following nursing diagnoses were elaborated: Irregular practice of exercise, Regular practice of exercise, Fatigue, Reduced strength, Effective walking and Impaired walking.

Bodily care in the everyday routine of individuals with diabetes must include specific activities, considering the endothelial and micro-circulatory alterations of the disease associated with alterations in the immunological response, which favor the development of skin lesions and infections. In this sense, we highlight the importance of careful and periodic evaluation of the skin of individuals with diabetes and the promotion of health education, focusing on actions to maintain skin health, involving metabolic control, skin hydration, hygiene, adequate clothes (including footwear) and protection. Daily inspection of the skin and the use of appropriate products prevent the appearance of these lesions ${ }^{(12)}$.

Taking as a basis the significance of these aspects for nursing care, the nursing diagnoses Self-care deficit (specify) and Effective self-care (specify) were elaborated.

Within the context of care for individuals with chronic diseases, such as diabetes, the concept of self-care covers not only bodily care but also the joint construction of a care plan on the basis of a priority chosen through negotiation between the healthcare professional and the user, i.e. understanding the various vulnerabilities of the latter party, familiarization with his/her condition and the establishment of a joint care horizon among all of the actors involved in the process. Within this context, the self-care to be developed with diabetic individuals involves three pillars: clinical management; changes in lifestyle and emotional aspects; and change in the vision of the future ${ }^{(13)}$.

The need for physical and cutaneo-mucosal integrity in diabetic individuals is generally affected by the presence of ulcers of the feet, also termed diabetic foot, which represents one of the chronic complications of the disease. Considered as a multi-disciplinary complication of diabetes, in order to reduce indices of amputation among this client base, at the various levels of care, healthcare professionals must be capacitated to identify and classify the patient at risk, applying early treatment and promoting individual, family and community education ${ }^{(14)}$. Specialized care is an important reference in the handling and treatment of diabetic foot, which demands specialized attention, with a vascular surgery and specific diagnostic examinations, such as the filament test, image examinations, doppler, arteriography, angioplasty, etc.
In order to recognize the importance of the complications deriving from this need for individuals with diabetes, the nursing diagnoses Skin integrity preserved, Skin integrity impaired, Wound (specify location), Risk of diabetic foot, Pruritus (specify location), Healing impaired and Effective healing were elaborated.

Alterations in the need for thermal regulation may be highlighted in individuals with diabetes arising from infection processes, most notably in lesions of the lower limbs and in cases of decompensation of the disease, hypoglycemia episodes occur. Due to the need to give attention to these situations, the nursing diagnoses Hyperthermia and Hypothermia were elaborated.

The need for regulation of hormones is a fundamental element for individuals with diabetes, since its physiopathology is directly related to defects in the secretion and/or production of the hormone insulin, which is responsible for the control of blood glucose. These disequilibria in diabetes translate into alterations of the level of glucose in the blood, entailing acute complications which demand urgent care. In view of the circumstances, the nursing diagnoses Hyperglycemia and Hypoglycemia were elaborated.

Hyperglycemia is characterized by the high level of glucose in the blood, specific to the definition of diabetes and when not controlled, may, in the long term, cause multiple organ dysfunctions and failure, especially of the kidneys, eyes, nerves, heart and blood vessels. Serious and potentially fatal complications may develop, such as diabetic ketoacidosis and hyperosmolar hyperglycemic non-ketotic syndrome. In order for treatment to be successful, the involvement of an entire multi-professional team ${ }^{(9)}$ is necessary.

Hypoglycemia, the opposite event to hyperglycemia, is the reduction in glycemic levels to values below $70 \mathrm{mg} / \mathrm{dl}$, which may take the form of early signals, such as tremors, tachycardia, sweating and hunger and may evolve into headache, anxiety, loss of consciousness, motion and coma ${ }^{(9,12)}$. According to the seriousness of the hypoglycemia, its treatment consists of the ingestion of carbohydrates or the administration of endovenous glucose. At the same time, adequate treatment for preventing these episodes involves adjustments to medication, physical activity, eating, monitoring of capillary glycaemia, as well as a continuous process of education, which motivates adhesion to the treatment ${ }^{(11)}$.

Neurological regulation is related to mental activity. Studies have demonstrated that the effect of diabetes on the brain has contributed to increasing the degree of compromising of cognitive functions and suggests that type 2 $\mathrm{DM}$ accelerates the cognitive deficit process, increasing the possibility of developing dementia, which is prevalent in an elderly population ${ }^{(15)}$. Corroborating the previous study, a systematic review points to an association between type $2 \mathrm{DM}$ and impaired cognitive performance in the elderly, predominantly related to executive functions, including flexibility of thought, attention and working memory ${ }^{(16)}$. Taking into consideration the involvement of disequilibria of this need in the education process of the individual with diabetes, the nursing diagnostic Impaired memory was elaborated. 
Alterations in the need for vascular regulation are present in the natural history of diabetes and form the physiopathological basis of chronic complications, classified as macrovascular and microvascular diseases. Macrovascular diseases are more common in individuals with type 2 diabetes and include ischemic cardiovascular diseases: coronary disease, cerebrovascular disease and peripheral vascular disease. Microvascular diseases include diabetic retinopathy, diabetic nephropathy and diabetic neuropathy ${ }^{(9)}$. Preventing these complications is a major challenge in the treatment of the evolution of diabetes.

In order to do this, the control of risk factors must be used as the principal strategy. Contemplating this strategy, the nursing diagnoses Hypertension and Altered blood pressure were elaborated.

Hypertension is directly associated with diabetes and is one of the risk factors for both chronic macrovascular and microvascular complications, with its approach to be included in the initial assessment consultation of individuals with diabetes, assisting with the stratification of cardiovascular risk and relating its prevention and control to changes in lifestyle, covering healthy eating habits, regular physical activity, reduction in the consumption of alcoholic beverages and giving up smoking ${ }^{(9)}$.

The needs of visual, auditory, tactile and pain perception are experienced with alterations in individuals with diabetes as a consequence of their macrovascular and microvascular complications. In order to understand the importance of analyzing the presence of these changes in the evaluation of these individuals, the following nursing diagnoses were elaborated: Normal vision, Impaired vision, Normal hearing, Impaired hearing, Reduced sensitivity (specify location), Pain (specify intensity and localization), Headache (specify intensity), Epigastric pain (specify intensity), Muscular pain (specify intensity) and Musculo-skeletal pain (specify intensity).

Impaired vision is a frequent alteration among individuals with diabetes, which is generally associated with the duration of the disease and the lack of glycemic control. It may appear as a loss of visual acuity, going as far as blindness, which may occur as a consequence of ocular diseases, such as diabetic retinopathy, macular edema, cataract and glaucoma ${ }^{(9)}$. The study highlights the interference of this alteration in the daily lives of these individuals, frequently demarcating limits and demanding new forms of adaptation and treatment and pointing to the need for a new stance by professionals, in the sense of helping them to live with this new situation and to use new tools, such as crutches and reading Braille ${ }^{(17)}$.

Impaired hearing in clinical practice among individuals with diabetes is not a common element, which has led to controversies regarding its causality in the specialist literature. While these limits are considered in the cause and effect relationship between diabetes and loss of hearing, the study highlights symptoms such as fluctuating hypoacusis, sensory hearing impairment, tinnitus and sensation of auricular plenitude and suggests the inclusion of a complete audiological evaluation in type 1 diabetic patients ${ }^{(18)}$.

Diminished sensitivity occurs predominantly in the lower limbs, as a consequence of the complications of the dia- betic neuropathy, affects the quality of life of the individuals with diabetes and represents a potential risk of development of ulcerated lesions on the feet and deformations, which are important aspects at the time of assessment of the feet ${ }^{(12)}$.

Painful perception may be affected as the result of complications of diabetes, principally neuropathies, which are responsible for the appearance of pain in the lower limbs, which appear as intermittent pain, characterized by cramp or continuous pain, frequently in the calves, as well as nocturnal pain and pain while resting, due to ischemic neuritis.

The need for physical and environmental security has the objective of preserving physical and socio-environmental safety. The nursing diagnoses Use of alcohol and Use of tobacco were elaborated with regard to this need. The identification of these nursing diagnoses in individuals with diabetes is a most worrying factor, considering the complications which it may entail. In diabetes, In particular, the detrimental effects of smoking are related to increase risk of macro and microvascular disease ${ }^{(13)}$. On the other hand, alcohol reduces the blood glucose level, masks the signs of hypoglycemia and hinders the normalization of glycemic levels during hypoglycemic episodes ${ }^{(19)}$.

Therapeutic necessity, within the context of the diabetes, is a vital aspect for ensuring a better quality of life and for minimizing complications, with implications both for the client and for the healthcare professional. In this sense, an individual with diabetes is confronted on a daily basis with a need to develop a set of self-care behaviors for managing his or her condition. By contrast, healthcare professionals are confronted with a need to use strategies which promote motivation to adhere to a healthier lifestyle. The nursing diagnoses Adhesion to diabetes treatment, Self-monitoring of correct glycemia and Self-monitoring of incorrect glycemia were elaborated in view of this prospect.

Adhesion to diabetes treatment is one of the major challenges to be achieved in a public health scenario, which requires a new active attitude in providing care to this client base, in which the therapeutic protocol is established jointly between the healthcare professional and the client, in the sense of their becoming active participants in the health process, replacing the old prescriptive practices, which were not capable of achieving this outcome ${ }^{(20)}$. At the same time, in order to ensure this attitude, we highlight that an efficient investigation is required during consultations, in the sense of perceiving the psychological, social, cultural, family and many other factors which may interfere with the adhesion to treatment and with changes in lifestyle ${ }^{(20)}$.

Self-monitoring of glycemia has the purpose of directing therapy, in the direction of securing and maintaining glycemia as close as possible to normal, under special conditions or in the daily routine, always safely, being considered one of the seven forms of self-care behavior and one of the most important actions in treating diabetes. For this purpose, the effectiveness of monitoring depends on a number of factors related to practical aspects, ranging from the choice of glucometer to the performance of the technique ${ }^{(12)}$.

Emotional security is a need which may be placed at risk among clients with diabetes, since it is a chronic disease, 
which imposes limitations of different kinds, ranging from nutritional restrictions to incapacities resulting from the complications, contributing to the emotional and psychological fragility of this client base ${ }^{(9)}$. Considering the implications of such fragilities being able to interfere in the adhesion to the treatment of the diabetes, the nursing diagnoses Anxiety (specify type of degree), Fear (specify) and Negation of diabetes were elaborated.

In order to deal with negative emotions and the fragilities imposed by the limitations, a strategy of community groups is indicated, permitting an exchange of experiences, anxieties, fantasies and in securities, in which the individual learns to deal and live with the disease and to construct a healthier lifestyle, seeking to form a social support network. An experiment carried out with a group of individuals with diabetes highlighted that the success of being healthy with their chronic condition was achieved when the individuals succeeded in transcending their limitations and found the strength to deal with impossibilities and limitations ${ }^{(21)}$.

Among the Psychosocial Needs, learning, within the context of the nursing care for an individual with diabetes, has the objective of constructing shared knowledge on the health-disease-care process, so as to guarantee the right to individuals to decide on the most appropriate strategies for promoting, maintaining and recovering their health ${ }^{(22)}$. Considering the implications represented by these educational activities in changing the behavior of the individuals with diabetes and with a view to adhesion to the treatment, the following diagnoses were elaborated: Adequate knowledge of medication, Inadequate knowledge of medication, Adequate knowledge of exercises, Inadequate knowledge of exercises, Adequate knowledge of diabetes mellitus and Inadequate knowledge of diabetes mellitus.

Considering that education on diabetes forms an integral part of nursing care, empowering care will be characterized by an intentional activity, which allows the individual to acquire knowledge of him- or herself and his/her surroundings, to make changes to this environment and in his/her own conduct, being capable of defining his/her own problems and needs and developing a critical conscience, in the sense of his/her own autonomous and personalized way of living ${ }^{(23)}$.
The assessment of the need for one's own orientation in space and time must be emphasized for individuals with diabetes, considering that changes in this need, such as confusion and disorientation, may manifest themselves as symptoms of hypoglycaemia ${ }^{(9)}$. In these situations, we highlight the importance of family support for evaluating and detecting the symptoms. In this way, the nursing diagnoses Orientation in time and space preserved and Orientation in time and space impaired were elaborated.

Self-esteem, self-confidence, self-respect, attention and self-image may be compromised in individuals who receive the diagnosis of diabetes, considering the impact of the possible repercussions on their lives, since these generate different feelings and emotions. Considering such aspects, the nursing diagnoses Acceptance of diabetes, Positive self-image and Negative self-image were elaborated.

A study carried out on the emotional repercussions of the diagnosis of diabetes in the life history of the subject highlighted the emergence of feelings such as sadness, desolation and insecurity, culminating in a limited acceptance of the disease and of the therapeutic course. This highlights the importance of recognition by the healthcare professional of such emotional repercussions and their influence on health care ${ }^{(24)}$.

\section{CONCLUSION}

We highlight in this study that the use of $\mathrm{ICNP}^{\circledR}$ Terminology for the construction of nursing diagnoses favored the specifications of concepts of professional practice in health care aimed at individuals with diabetes, leading to care practice which focuses care and assistance priorities for this client base.

The statements of nursing diagnoses considered do not exhaust the domain of this health priority and other studies must be carried out in order to structure a proposal for a subset, with a view of contributing to nursing practice for this client base and to favoring the evidence of elements of the practice (diagnoses, outcomes and interventions), consequently highlighting the competences and activities of nursing practice in care for chronic diseases.

\section{RESUMO}

Objetivo: Construir enunciados de diagnósticos de enfermagem relacionados à prática de enfermagem para pessoas com diabetes na Atenção Especializada, com base no Banco de Termos da Linguagem de Enfermagem relacionado à diabetes, na Classificação Internacional para a Prática de Enfermagem $\left(\mathrm{CIPE}^{\circledast}\right)$ e na Teoria das Necessidades Humanas Básicas e validá-los com enfermeiros especialistas da área. Método: Pesquisa metodológica estruturada em etapas sequenciadas de construção, mapeamento cruzado, validação e categorização dos diagnósticos de enfermagem. Resultados: Apontaram uma lista de 115 enunciados de diagnósticos, incluindo-se enunciados positivos, negativos e de melhora; 59 diagnósticos de enfermagem constantes e 56 diagnósticos de enfermagem não constantes na CIPE $^{\oplus}$ Versão 2011. Foram validados 66 diagnósticos com IVC $\geq 0.50$, os quais foram categorizados com base nas necessidades humanas. Conclusão: Observou-se que o uso da CIPE 2011 favoreceu a especificação dos conceitos da prática profissional no cuidado com as pessoas com diabetes.

\section{DESCRITORES:}

Diagnóstico de Enfermagem; Diabetes Mellitus; Classificação; Terminologia.

\section{RESUMEN}

Objetivo: Construir enunciados de diagnósticos de enfermería relacionados con la práctica de enfermería para personas con diabetes en la Âtención Especializada, con base en el Banco de Términos del Lenguaje de Enfermería relacionado con la diabetes, en la Clasificación 
Internacional para la Práctica de Enfermería $\left(\mathrm{CIPE}^{\circledast}\right)$ y la Teoría de las Necesidades Humanas Básicas, y validarlos con enfermeros expertos del área. Método: Investigación metodológica estructurada en etapas secuenciadas de construcción, mapeado cruzado, validación y categorización de los diagnósticos de enfermería. Resultados: Señalaron un listado de 115 enunciados de diagnósticos, incluyéndose enunciados positivos, negativos y de mejora; 59 diagnósticos de enfermería obrantes y 56 diagnósticos de enfermería no obrantes en la CIPE ${ }^{\oplus}$ Versión 2011. Fueron validados 66 diagnósticos con IVC $\geq 0.50$, los que fueron categorizados con base en las necesidades humanas. Conclusión: Se observó que el uso de la CIPE 2011 favoreció la especificación de los conceptos de la práctica profesional en el cuidado con las personas portadoras de diabetes.

\section{DESCRIPTORES:}

Diagnóstico de Enfermería; Diabetes Mellitus; Clasificación; Terminología.

\section{REFERENCES}

1. Cubas MR, Silva SH, Rosso M. Classificação Internacional para a Prática de Enfermagem (CIPEß): uma revisão da literatura. Rev Eletr Enferm [Internet]. 2010 [citado 2012 mar. 29];12(1):186-94. Disponível em: http://www.fen.ufg.br/revista/v12/n1/pdf/v12n1a23.pdf

2. Cruz DALM. Diagnósticos de enfermagem. In: Garcia TR, Egry EY. Integralidade da atenção no SUS e sistematização da assistência de enfermagem. Porto Alegre: Artmed; 2009. p. 111-7.

3. Sociedade Brasileira de Diabetes. Diretrizes da Sociedade Brasileira de Diabetes: 2013-2014. São Paulo: AC Farmacêutica; 2014.

4. Tannure MC, Pinheiro AM. SAE: Sistematização da Assistência de Enfermagem: guia prático. 2ª ed. Rio de Janeiro: Guanabara Koogan; 2013.

5. Horta WA. Processo de enfermagem. Rio de Janeiro: Guanabara Koogan; 2011.

6. Brasil. Ministério da Saúde; Conselho Nacional de Saúde. Resolução n. 466, de 12 de dezembro de 2012. Dispõe sobre diretrizes e normas regulamentadoras de pesquisas envolvendo seres humanos [Internet]. Brasília; 2012 [citado 2013 mar. 29]. Disponível em: http://conselho. saude.gov.br/resolucoes/2012/Reso466.pdf

7. Leal MT. A CIPE® e a visibilidade da enfermagem; mitos e realidades. Loures (PT): Lusociência; 2006.

8. Alexandre NMC, Coluci MZO. Validade de conteúdo nos processos de construção e adaptação de instrumentos de medidas. Ciênc Saúde Coletiva [Internet]. 2011 [citado 2013 mar.14];16(7):3061-8. Disponível em: http://www.scielo.br/pdf/csc/v16n7/06.pdf

9. Brasil. Ministério da Saúde; Secretaria de Atenção à Saúde, Departamento de Atenção Básica. Estratégia para o cuidado da pessoa com doença crônica: diabetes mellitus. Brasília; 2013. (Cadernos de Atenção Básica, n. 36).

10. Vaughans BW. Fundamentos de enfermagem desmistificados: um guia de aprendizado. Porto Alegre: AMGM; 2012.

11. American Diabetes Association. Standards of Medical Care in Diabetes - 2014. Diabetes Care [Internet]. 2014 [cited 2014 Feb 11];37 Suppl 1:S14-80. Available from: http://care.diabetesjournals.org/content/37/Supplement_1/S14.extract

12. Grossi SAA, Pascali PM. Cuidados de enfermagem em diabetes mellitus. Itapevi: AC Farmacêutica; 2011.

13. Brasil. Ministério da Saúde; Secretaria de Atenção à Saúde, Departamento de Atenção Básica. Estratégia para o cuidado da pessoa com doença crônica. Brasília; 2014. (Cadernos de Atenção Básica, n. 35).

14. Caiafa JS, Castro AA, Fidelis C, Santos VP, Silva ES, Sitrângulo Junior CJ. Atenção integral ao portador de pé diabético. JVasc Bras. 2010;10(4 Supl. 2):1-32.

15. Lopes RMF, Argimon IIL. Idosos com diabetes mellitus tipo 2 e o desempenho cognitivo no teste Wisconsin de classificação de cartas (WCST). Univ Psychol. 2010;9(3):697-714.

16. Lopes RMF, Nascimento RFL, Wendt GW, Argimon IIL. A diabetes mellitus causa deterioro cognitivo em idosos? Um estudo de revisão. Av Psicol Latinoam. 2013; 31(1):131-9.

17. Andrade NHS, Zanetti ML, Santos MA. A percepção visual de pacientes com retinopatia diabética, segundo o referencial de Merleau-Ponty. Rev Enferm UERJ [Internet]. 2008 [citado 2014 fev. 23];16(2):249-54. Disponível em: http://www.facenf.uerj.br/v16n2/v16n2a18.pdf

18. Malucelli DA, Malucelli FJ, Fonseca VR, Zeigeboim B, Ribas A, Trotta F, et al. Estudo da prevalência de hipoacusia em indivíduos com diabetes mellitus tipo 1. Braz J Otorhinolaryngol. 2012;78(3):105-15.

19. Lima MHM, Araújo EP. Paciente diabético: cuidados em enfermagem. Rio de Janeiro: MedBook; 2012.

20. Santo BEM, Souza LME, Souza ACG, Ferreira FM. Adesão dos portadores de diabetes mellitus ao tratamento farmacológico e não farmacológico na atenção primária à saúde. Enferm Rev. 2012;15(1):88-101.

21. Francioni FF, Silva DGV. O processo de viver saudável de pessoas com diabetes mellitus através de um grupo de convivência. Texto Contexto Enferm. 2007;16(1):105-11.

22. Borba AROT, Marques APO, Leal MCC, Ramos RSPS. Práticas educativas em diabetes mellitus: revisão integrativa. Rev Gaúcha Enferm [Internet]. 2012 [citado 2014 jan. 23];33(1):169-76. Disponível em: http://www.scielo.br/pdf/rgenf/v33n1/a22v33n1.pdf

23. Hammerschimdt KSA, Lenardt MH. Tecnologia educacional inovadora para o empoderamento junto a idosos com diabetes mellitus. Texto Contexto Enferm [Internet]. 2010[citado 2014 fev. 18];19(2):358-65. Disponível em: http://www.scielo.br/pdf/tce/v19n2/18.pdf

24. Ferreira DSP, Daher DV, Teixeira ER, Rocha IJ. Repercussão emocional diante do diagnóstico de diabetes mellitus tipo 2. Rev Enferm UERJ [Internet]. 2013 [citado 2014 maio 24];21(1):41-6. Disponível em: http://www.facenf.uerj.br/v21n1/v21n1a07.pdf 